\title{
Strategi Pelayanan Pastoral Bagi Kaum Awam Menurut Bapa Gereja Gregorius Agung
}

\author{
Hendi, Syelin Umur \\ Sekolah Tinggi Teologi Soteria Purwokerto, Indonesia \\ Email: hendi@sttsoteria.ac.id
}

\begin{tabular}{|l|l|l|}
\hline Diterima: 2 Oktober 2019 & Direvisi: 26 Februari 2020 & Disetujui: 11 Juni 2020 \\
\hline
\end{tabular}

\begin{abstract}
Abstrak
Latar belakang dan karakteristik setiap umat sungguh beragam. Dan seorang pastor atau gembala memikul tanggung jawab untuk melayani atau menggembalakan mereka. Seorang pastor harus memiliki mata yang tajam dan strategi yang tepat untuk melayani umat yang sangat beragam. Kecakapan seorang pastor diperlukan dalam pelayanan penggembalaan. Artikel ini akan mengupas atau menguraikan strategi pelayanan pastoral yang diajarkan oleh Bapa Gereja yang bernama Gregorius Agung. Gregorius Agung menekankan setiap pastor seharusnya bisa melihat dan melayani kebutuhan spiritual yang berbeda dari setiap umat. Gregorius Agung mengajarkan pentingnya nasihatnasihat spiritual yang berbeda sesuai dengan karakter dan kondisi umat yang dilayani. Ada 11 kualifikasi dan 40 strategi bagi para pastor menggembalakan umatnya dengan spirit kerendahan hati seperti teladan dari Sang Gembala Agung Yesus Kristus.
\end{abstract}

Kata-Kata Kunci: Kerendahan hati; Kasih; Menasihati; Pelayan pastoral; Strategi.

\section{Abstract}

The knowledge of a pastoral minister or priest will be in vain and will not affect the maturity of the faith of the church if it cannot be expressed. This is reflected in the inability of a pastor / priest when facing the world of service that requires struggle and sacrifice so that a good strategy is needed in its implementation. It is intended that pastors can see and serve the different 
spiritual needs of each congregation. The strategy in question can be channeled through teaching such as giving advice to various characteristics of the congregation. There are 11 qualifications and 40 strategies outlined by the Church Father Gregory the Great to become a priest who is as loving and humble as the example of the Great Shepherd of Jesus Christ.

Keywords: Advise; Humility; Pastoral servants; Strategies.

\section{Pendahuluan}

Para bapa gereja mendefinisikan bahwa gereja adalah rumah sakit bagi orang-orang berdosa. Hal tersebut mengindikasikan bahwa gereja hadir untuk melayani dan memberikan penanganan yang berguna dan tepat bagi jiwa seseorang yang sedang sekarat atau mati akibat dosa (Ef 2:1). Gereja sebagai rumah sakit memiliki kontribusi besar bagi keselamatan umat manusia, dan hal ini dapat diwujudkan melalui berbagai model pelayanan gereja yang dijalankan oleh para pelayan gereja seperti para penatua ${ }^{1}$ atau pastor atau gembala gereja dalam bahasa awamnya maupun para umat gereja lainnya seperti diaken-diaken. Hal ini sangat penting karena seorang penatua atau pastor berperan sebagai contoh atau model Kristus yang nyata di hadapan umat sehingga perlu bagi mereka menunjukkan teladan hidup. Jika ditinjau kembali keberadaan kehidupan gereja pada saat ini, khususnya di Indonesia, statistik menunjukkan bahwa perhatian akan keteladanan seorang pastor menjadi kunci keberhasilan pelayanan gerejawi. Sebagai contoh, adanya kepincangan ketika seorang pastor menekankan kebenaran namun ternyata tidak teraplikasi di dalam kehidupan pribadinya dan pada akhirnya menjadi contoh buruk bagi umat dan orang yang belum percaya pada Kristus. Hal ini terjadi akibat kelalaian pastor dalam hal tingkah laku atau karakternya dalam pelayanan. ${ }^{2}$

Karakter seorang pastor sangat memengaruhi kehidupan jemaat dan seorang pastor perlu dibekali sebuah model gembala yang sejati. Model tersebut dijumpai dalam diri Yesus Kristus sebagai Gembala Sejati, sebagai teladan bagi semua pastor. Dalam Injil, Yesus menjelaskan sifat dan tugas-Nya dalam berbagai macam perumpamaan namun Yesus lebih menggemari

${ }^{1}$ Dalam artikel ini istilah penatua yang dipakai adalah pastor atau gembala gereja.

2 Associated Press, "Pemecatan 400 Pendeta Oleh Vatikan," Jawaban.com, 2012. Berbagai isu menerpa gereja seperti kasus pelecehan seksual, perselingkuhan, dan korupsi. Berikut beberapa kasus yang tercatat: Sebuah dokumen yang diperoleh Associated Press (AP) memperlihatkan data statistik tahun 2011 dan 2012 mengenai langkah pemecatan dari Vatikan selama kepemimpinan Paus Benediktus XVI kepada hampir 400 pendeta yang diklaim terlibat pelecehan seksual terhadap anak-anak. (diakses 25 Nopember 2019) 
mengumpamakan diri-Nya sebagai seorang gembala yang baik, ${ }^{3}$ yang akan berkorban dan mengasihi domba-dombanya. Pertanyaan Yesus kepada Petrus dalam Yohanes 21:17 menekankan betapa pentingnya sebuah kasih yang harus dimiliki seorang pastor baik kepada Allah maupun terhadap domba (jemaat). Derek J. Tidball mendefinisikan bentuk kasih seorang gembala dalam pernyataannya, bahwa pastor yang bersedia berjalan bersama jemaat dalam melewati krisis dan penderitaan hidup merupakan perwujudan dari kehidupan seorang gembala yang menuntun domba. ${ }^{4}$

Seorang pastor yang baik harus memahami kehidupan dombanya yang memiliki perbedaan kebutuhan, karena pada dasarnya manusia diciptakan berbeda begitu pula dengan kebutuhannya. Namun sayangnya, pada saat ini para pastor masih memiliki pengetahuan yang terbatas mengenai pembimbingan yang tepat sehingga kurang memahami pentingnya hal tersebut. Akibatnya muncul berbagai masalah yang terjadi dalam gereja akibat kurangnya pengetahuan seorang gembala dalam memahami orang yang dibimbing.

Permasalahan di atas perlu disikapi secara serius, sebab jika diabaikan akan memengaruhi pertumbuhan iman seseorang bahkan lebih buruk lagi meninggalkan imannya. Seorang pastor dikatakan telah gagal karena tidak dapat mencerminkan karakter Kristus sebagai gembala yang baik dan penuh kasih. Seorang pastor tidak cukup hanya memiliki pengetahuan dalam berkhotbah tetapi juga memiliki keterampilan dalam mempraktikkan proses pembimbingan seseorang dalam pengenalannya akan Krsitus. Oleh sebab itu, seorang pastor membutuhkan strategi atau suatu penyusunan rencana yang cermat mengenai kegiatan untuk mencapai sasaran khusus. Seorang Bapa Gereja yang bernama Gregorius Agung dalam bukunya berjudul The Book of Pastoral Rule telah memberi perhatian khusus terhadap masalah di atas. Bukunya menjadi ulasan penulis di dalam artikel ini sehingga para pembaca, terutama para pastor, dapat mengikuti panduan pelayanan pastoral yang diberikan.

Gregorius Agung lahir pada tahun 540 dan berasal dari keluarga berkebangsaan Romawi. Gregorius juga menjalani pendidikan di salah satu universitas terbaik di Roma dan senang mempelajari ajaran-ajaran dari Cicero,

${ }^{3}$ Charles Jefferson, The Minister as Shepherd (Hongkong: Mimery Press, 1997), 16.

${ }^{4}$ Derek J Tidball, Teologi Pengembalaan (Malang: Gandum Mas, 1995), 383.

${ }^{5}$ Buku ini ditulis oleh Gregorius kepada pemimpin gereja Yohanes di Revenna pada tahun 590. Buku ini ditulis oleh Gregorius ketika melihat begitu banyak penyiksaan kepada gereja yang menimbulkan krisis iman dalam kekristenan. Buku ini juga semakin menyebar luas dan diterjemahkan dalam berbagai bahasa. Dan ditujukan khususnya bagi para bishop di Antiokhia, Spanyol, Inggris, dan negara lainnya. 
Seneca, dan Virgil. Hasilnya, ia memiliki karir yang sukses di Roma. Pada tahun 574, Gregorius secara total mengalami perubahan hidup. Ia berhenti dari karirnya, menjual semua harta milik keluarganya, serta mengawali kembali kehidupannya yang baru dalam biara Roma. Lima tahun kemudian (thn. 579), Gregorius dipindahkan ke dalam lembaga Kekaisaran Konstantinopel oleh Paus Pelagius II sebagai pemimpin biara. Gregorius menghabiskan masa hidupnya selama 7 tahun dalam lembaga tersebut. Tahun 585 ia menjadi kepala biara di Roma. Pada tahun yang sama, Gregorius mulai menjalin relasi dengan para pemimpin gereja bagian Timur. Gregorius juga dianggap memiliki perspektif teologi yang sama dengan Augustinus. Karena pada dasarnya Gregorius meluruskan kembali berbagai pengajaran mengenai pastoral, keselamatan, dan kehidupan asketis dari para Bapa Gereja Timur. Gregorius juga setia melayani persediaan makanan para fakir miskin di Roma dan memerbaiki sistem gereja yang telah rusak. Ia berkontribusi besar dalam pelayanan kepedulian gembala yang sangat berpengaruh di sepanjang sejarah gereja. ${ }^{6}$

Seperti apa seorang pastor, dan bagaimana seorang pastor menjalankan pelayanan pengembalaannya? Gregorius menyatakan ada 11 kualifikasi dan 12 karakter dalam menjalankan pelayanan pastoral yang merupakan sebuah bentuk kedisiplinan secara jasmani maupun rohani. Serta ada 40 bentuk strategi penggembalaan bagi kaum awam yang memiliki kebutuhan yang berbeda-beda.

\section{Metode Penelitian}

Tulisan ini menggunakan metode penelitian literatur. Penulis menggunakan buku The Book of Pastoral Rule sebagai buku yang menjadi landasan teori dalam membahas strategi pelayanan pastoral bagi kaum awam. Penulis membahas strategi pelayanan pastoral menurut Gregorius dengan menggunakan 11 kualifikasi pastoral, 40 strategi pelayanan pastoral, dan pentingnya kerendahan hati dalam pelayanan pastoral. Penjelasan ini kemudian dijabarkan melalui interaksi dengan teks-teks lain di dalam Alkitab dan berbagai sumber sekunder yang mendukung.

\section{Pembahasan dan Hasil}

Pastor adalah seseorang yang bertugas sebagai pemimpin rohani atau gembala di sebuah gereja. Pemimpin rohani di sini bisa merupakan jabatan

\footnotetext{
2019.

${ }^{6}$ Lihat http://www.newadvent.org/cathen/06780a.htm. Diakses pada tanggal 2 Februari
} 
episkop, penatua, dan diaken di dalam gereja. Anthony M. Coniaris menuliskan bahwa, "Theology orthodox is not static but dynamic; it is not a state of being, a state of having arrived, a state of having made it, but a conscant movement or climbing towards theosis, towards Christ-likeness, toward receiving the fullness of God's life". ${ }^{7}$ Teologi Ortodoks memahami konsep keselamatan seseorang hanya dapat ditempuh melalui perjuangan yang konstan untuk menjadi serupa dengan Kristus dan menyatu dengan Dia. Oleh sebab itu, seorang pastor perlu melakukan perjuangan keras untuk melakukan tugasnya.

Untuk menggambarkan tugas seorang pastor Coniaris mengutip perkataan Ishak dari Siria yang menekankan bahwa seorang pastor seharusnya, "Enter eagerly into the treasurehouse (the heart) that lies within you, and so you will see the treasurehouse of heaven. For the two atre the same, and there is but one single entry to them both. The leadder that leads to the kingdom is hidden within you, and is found in your soul. Dive into yourself, and in your soul you will discover the rungs by which you are to ascend". ${ }^{8}$ Paulus mendeskripsikan konsep pendamaian tersebut dalam suratnya sebagai berikut: "Dan oleh Dialah, Ia memperdamaikan segala sesuatu dengan diri-Nya, baik yang ada di bumi, maupun yang ada di sorga, sesudah Ia mengadakan pendamaian oleh darah salib Kristus." (Kol 1:20). Semua orang yang berdosa hanya dapat diperdamaikan dengan Allah melalui pengorbanan Yesus Kristus. Dengan begitu, seorang pemimpin rohani khususnya para pastor memiliki tanggung jawab untuk membawa, membimbing, dan memimpin seseorang kepada Kristus. Para rasul juga mengakui bahwa pendamaian ini telah menjadi berita yang dipercayakan Allah untuk diberitakan (2 Kor 5:18).

\section{Kualifikasi Seorang Pastor}

Gregorius menekankan kriteria-kriteria bagi seseorang untuk ditahbis menjadi seorang pastor. Bagi Gregorius kriteria ini sangat penting karena dia percaya bahwa gereja akan bangkit jika dipimpin oleh para pastor atau penatua gereja yang berkualitas. Berikut kriteria-kriteria yang diajukan oleh Gregorius bagi gereja.

Memiliki pengalaman

Salah satu upaya yang perlu dilakukan yaitu memiliki pengalaman dalam kehidupan rohani maupun jasmani. Kedua hal ini mencakup emosi, karakter,

${ }^{7}$ Anthony M Coniaris, Philokalia: The Bible of Orthodox Spirituality (Minneapolis: Library of Congress, 1998), 233.

${ }^{8}$ Coniaris, Philokalia: The Bible of Orthodox Spirituality. 
dan kecerdasan. ${ }^{9}$ Yosafat Bangun juga menegaskan bahwa tanpa pengalaman seorang gembala akan mengalami kesulitan menangani masalah yang timbul dalam pelayanannya. ${ }^{10}$ Musa juga menuliskan orang yang melayani tanpa pengalaman bagaikan orang yang memersembahkan api yang asing dihadapan Allah (Im 10:1). Jadi, pengalaman penting sebagai persiapan seorang pelayan sebelum memasuki medan pelayanan.

Kemampuan untuk Memraktikkan Apa yang Telah Dipelajari dan Apa yang Diajarkan

Gregorius menyebutkan bahwa perbuatan seorang pastor yang buruk akan mengotori air yang diberikan kepada para domba (jemaat/umat). Sebaliknya perbuatan yang benar, akan menjamin kesehatan para domba". ${ }^{11}$ Dengan demikian perbuatan seorang pastor mempengaruhi pengajarannya. Perbuatan seorang pastor yang kotor oleh dosa tidak dapat membimbing jemaat kepada keselamatan. Hal ini terjadi karena aliran tersebut terhalang oleh perbuatan dosa bahkan menjadi batu sandungan bagi jemaat (Yeh 44:12).

\section{Menjaga Hati Saat Keadaan Kesulitan Terlebih Saat Keadaan yang Sukses}

Gregorius menjelaskan bahwa kenyamanan yang berlebihan pada otoritas dapat melengahkan kewaspadaan seorang pastor terhadap serangan atau godaan Iblis sehingga sadar atau tidak ia akan mengabaikan hal-hal yang perlu dilayani demi menjaga otoritasnya yang tinggi. ${ }^{12}$ Yesus sebagai Gembala Agung lebih memilih untuk mengasingkan diri dan berdoa ketika banyak orang mencari dan ingin menjadikan-Nya Raja. Hal ini menunjukan bahwa Yesus lebih memilih untuk mendekatkan diri kepada Allah ketika otoritas, kekuasaan (tawaran duniawi yang terlihat menyenangkan) sedang mengejar-Nya (Luk 5:16).

\section{Memiliki Pemikiran yang Fokus Sebelum Melayani}

Seorang pelayan pastoral perlu memfokuskan pikirannya dalam melayani suatu hal untuk mencapai hasil yang maksimal. Menempatkan pikiran pada kondisi yang tepat pada berbagai hal tentang kehidupannya sendiri pada saat melayani. Kesibukan seorang Pastor dalam memikirkan hal lain akan

${ }^{9}$ Gregorius The Great, The Book of Pastoral Rule (New York: St. Vladimir's Seminary Press, 2007), 29-31.

${ }^{10}$ Yosafat Bangun, Integritas Pemimpin Pastoral (Yogyakarta: Andi, 2014), 28.

${ }^{11}$ Great, The Book of Pastoral Rule.

${ }^{12}$ Great. 
memengaruhi keberhasilan pelayananya. Dalam posisi yang tidak memungkinkan, Daniel memfokuskan segenap hati dan pikiran untuk menegur sang raja sehingga membuatnya berbalik dari kejahatan (Dan 4:27). ${ }^{13}$

\section{Tidak Meninggalkan Pelayanan Demi Mengejar Kepentingan Pribadi}

Rasul Paulus menasihatkan Timotius, "Bertandinglah dalam pertandingan iman yang benar dan rebutlah hidup yang kekal. Untuk itulah engkau telah dipanggil dan telah engkau ikrarkan ikrar yang benar di depan banyak saksi." (1 Tim 6:12). Artinya, seorang pastor tidak hanya memperjuangkan imannya tetapi juga mendorong orang yang dipimpinnya untuk berjuang bersama. Gregorius menyamakan mereka seperti seorang yang berjalan dengan hanya mengenakan satu kasut dikakinya. ${ }^{14}$

\section{Memiliki Kerendahan Hati Sebagai Bukti Ketaatan pada Ketetapan Ilahi}

Kerendahan hati merupakan suatu ketentuan dasar pelayanan sebagai gambaran pengorbanan Yesus yang nyata. Yesus sebagai gembala yang agung telah menyelesaikan kehidupan dengan penuh ketaatan kepada Bapa. Kerendahan hati melaksanakan keinginan Bapa merupakan wujud ketaatan-Nya. Jadi, kerendahan hati seorang Pastor adalah bukti ketaatannya kepada Allah. Salah satu contoh yaitu mengelola ego sebagai bukti ketaatan kepada kehendak ilahi. Yesus rela melepaskan kemuliaan-Nya, kebahagiaan-Nya demi kehendak Bapa; dan rela menjadi manusia, lahir dikandang domba yang begitu sederhana, mati di atas kayu salib sebagai orang yang terkutuk demi keselamatan manusia (Yoh 3:16). ${ }^{15}$

\section{Tetap Melayani Walaupun dengan Gaya Pelayanan yang Berbeda}

Ada berbagai bentuk pelayanan yang dapat dilakukan seorang pastor sesuai dengan kemampuan yang diberikan Tuhan (Rom 12:6-8). Apapun bentuk gaya atau jenis pelayanan seorang pastor harus selalu bersumber dari sumber yang sama yaitu cinta akan Kristus dan sesama. ${ }^{16}$ Jadi, seorang pastor mungkin akan memiliki sikap hati yang akan selalu berubah dan memiliki cara yang berbeda dalam melayani. Akan tetapi, penting untuk tetap fokus kepada perintah

\footnotetext{
${ }^{13}$ Great.

${ }^{14}$ Great.

15 Great.

${ }^{16}$ Great.
} 
dan kehendak Allah yaitu mengasihi dan membawa para domba (jemaat) kepada keselamatan dari Allah.

\section{Tidak Menggunakan Ungkapan Kerasulan demi Kepentingan Pribadi}

Jabatan dan pujian manusia hanya akan menjadi pemuasan kepentingan pribadi karena itu seorang pastor harus mengutamakan kepentingan ilahi. Alasannya ialah kepuasan pribadi akan membawanya pada ambang pintu kesombongan. Dengan demikian pikiran seorang pastor harus dibentengi dengan doa dan firman setiap hari. ${ }^{17}$

\section{Tidak Mengejar Keunggulan dengan Cara Memberikan Janji Kosong}

Gregorius mengatakan bahwa ketika seorang pelayan merasa penghargaan adalah suatu kebutuhan penting maka ia telah memberikan kesempatan kepada keinginannya untuk berkuasa. Dalam pandangan mata jasmani terlihat baik namun memiliki motif tersembunyi yaitu melayani kesombongan. Seorang pastor memiliki fungsi yang sama dengan pelayanan kerasulan yaitu memiliki karunia-karunia rohani yang berbeda satu sama lain. Karunia yang diperoleh berasal dari Allah dan pasti akan tergenapi. ${ }^{18}$

\section{Menjadi Model yang Berkualitas Bagi Semua Orang}

Gregorius menyatakan bahwa seorang pastor tidak boleh melakukan tindakan jahat tetapi malah menyesali kejahatan yang dilakukan oleh orang lain seolah itu adalah miliknya. Inilah tanggung jawab yang dibawa seorang pastor dan memberikan kesadaran bagi para pelayan untuk memerhatikan langkah kehidupannya sebagai model kebenaran. ${ }^{19}$

\section{Tahu Mengukur Diri Sendiri}

Rasul Paulus menjelaskan bahwa, "Karena semua orang telah berbuat dosa dan telah kehilangan kemuliaan Allah." (Rom 3:23) Akan tetapi, kasih karunia Allah memampukan setiap orang untuk hidup dalam kebenaran (Rom 6:23). Seorang pelayan pastoral yang bertanggung jawab dalam pembimbingan kepada keselamatan harus terlebih dahulu menyerahkan hidup dalam kebenaran dan menjauhi dosa. Dengan demikian, seorang pastor akan bertanggung jawab atas dua hal yaitu menjauhkan dosa dari dirinya dan orang lain. Marlin Carothers

\footnotetext{
${ }^{17}$ Great.

18 Great.

${ }^{19}$ Great.
} 
menegaskan bahwa, "Strategi iblis yaitu dengan memikat orang percaya untuk menginginkan hal-hal yang tidak Allah inginkan. Kemudian, ketika keinginan itu tercipta, iblis akan terus memerkuatnya dan terus menggiringnya melebihi kerinduan seseorang untuk taat pada Allah". ${ }^{20}$ Akan tetapi, seorang pastor perlu berjuang karena Allah menghendaki semua orang termasuk seorang pelayan pastoral untuk berjuang melakukan kehendak-Nya (Luk 13:24). ${ }^{21}$

\section{Strategi Pelayanan Pastoral}

Pada bagian ini Gregorius membahas bagaimana pelayanan pastoral ditujukan kepada setiap umat berdasarkan karakternya. Gregorius menuliskan, "Therefore, the discourse of the teacher should be adapted to the character of his audience so that it can address the specific needs of each individual and yet never shrink from the art of communal edification". ${ }^{22}$ Berikut beberapa kategori dan strategi pelayanan pastoral.

\section{Laki-Laki, Perempuan, Orang Muda, dan Orang yang Tua}

Manusia baik laki-laki maupun perempuan diciptakan secara berbeda sehingga membutuhkan penanganan berbeda. Gregorius mengatakan bahwa seorang laki-laki cenderung membutuhkan nasihat yang berupa dorongan semangat untuk menjalani kehidupan. Berbeda dengan wanita yang cenderung lebih membutuhkan nasihat yang penuh dengan kelembutan dan kasih. ${ }^{23}$ Keberadaan para perempuan yang menjadi orang pertama mengambil buah membuat dirinya dicap sebagai penyebab kejatuhan manusia dalam dosa. ${ }^{24}$ Oleh sebab itu, seorang perempuan memerlukan kasih sayang dan kelembutan dari orang-orang disekelilingnya. Sebaliknya, seorang pastor perlu menggunakan cara penanganan yang terbuka dan jujur. ${ }^{25}$ Akan tetapi, dalam nasihatnya Rasul Paulus menyebutkan orang muda rentan terhadap hawa nafsu jahat sehingga perlu mengontrol diri (Tit 2:6). Dalam menghadapi kenyataan tersebut, seorang pastor diharapkan mampu menunjukan titik kesalahan mereka. Mengenai hal ini Rasul Paulus mengajarkan, "Janganlah engkau keras terhadap orang yang tua, melainkan tegorlah dia sebagai bapak. Tegorlah orang-orang muda sebagai

${ }^{20}$ Marlin Carothers, Jatuhnya Seorang Hamba Tuhan (Malang: Gandum Mas, 1990), 13.

${ }^{21}$ Great, The Book of Pastoral Rule.

${ }^{22}$ Great.

${ }^{23}$ Great.

${ }^{24}$ Anne Hommes, Perubahan Peran Pria Dan Wanita Dalam Gereja Dan Masyarakat (Jakarta: BPK Gunung Mulia, 1992), 80.

${ }^{25}$ Great, The Book of Pastoral Rule. 
saudaramu" (1 Tim 5:1). Pemberian teguran dengan bijak dan penuh kesabaran akan menolong mereka.

\section{Orang Kaya dan Orang Miskin}

Keduanya harus diberitahu untuk berusaha memberi bukannya memohon atau mencari harta dunia yang bersifat sementara. ${ }^{26}$ Gregorius menggambarkannya seperti amarah dan kekerasan hati dari orang gila dapat ditenangkan oleh perkataan lembut seorang dokter. ${ }^{27}$ Jadi, orang kaya harus dinasihati dengan kelembutan yang bertujuan. Sebagaimana Raja Saul yang dikenal keras kepala dapat ditenangkan dengan kelembutan suara musik harpa yang dimainkan oleh Daud (1 Sam 18:10). Orang miskin perlu dinasihati untuk berjuang akan harta surgawi yang tak terlihat dan bersifat abadi. ${ }^{28}$

\section{Orang yang Senang dan Sedih}

Orang yang senang perlu dinasihati agar tetap waspada akan perasaan sedih yang akan menimpanya. Yesus sebagai Guru Agung berkata, "Celakalah kamu, yang sekarang ini kenyang, karena kamu akan lapar. Celakalah kamu, yang sekarang ini tertawa, karena kamu akan berdukacita dan menangis" (Luk 6:25). Oleh sebab itu, seorang pastor perlu menasihati mereka untuk mempertahankan kekuatan mereka, jangan mudah menyerah ketika mengalami kesedihan. ${ }^{29}$ Dengan demikian ia perlu memberikan motivasi untuk berjuang bagi mereka yang senang sebagai persiapan dalam menghadapi kesedihan. Seorang pastor perlu memberikan harapan akan sukacita kekal yang sedang menantinya. Penerapan akan hal ini dapat berupa pemberian ucapan yang menginspirasi. ${ }^{30}$ Rasul Yohanes juga menegaskan bahwa Allah akan menghapus setiap air mata dan dukacita dari anak-anak-Nya (Why 21:4).

\section{Pengikut dan Pemimpin}

Pastor seharusnya dapat memberikan kesadaran terhadap para pengikut akan pentingnya ketaatan terhadap tuannya di dunia. Ketaatan terhadap pemimpin adalah salah satu bukti kasih terhadap Tuhan. Ray Regnaldi menambahkan bahwa ketaatan yang dimaksud di sini menuntut kesetiaan,

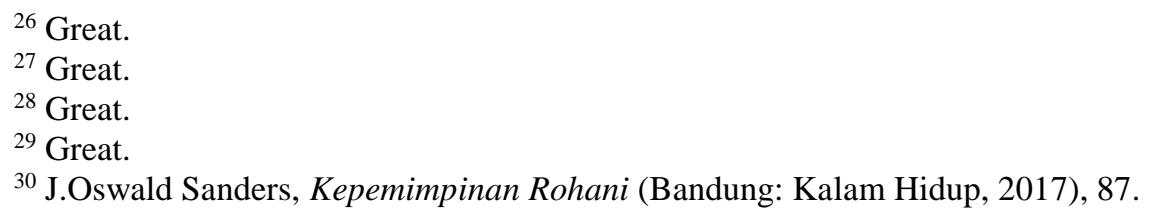


kesediaan melaksanakan perintah. ${ }^{31}$ Seorang pastor perlu menekankan bahwa ketaatan yang dimaksud bukanlah karena takut tetapi oleh karena kasih. Rasul Paulus menggambarkan seperti ketaatan seorang anak kepada ayahnya (Kol. 3:20). Hal ini akan mengarahkan seorang pengikut untuk melakukan segala hal yang baik bagi tuannya sebagaimana terhadap Allah. Pemimpin perlu dinasihati untuk mengelola emosi dengan baik agar tidak menjerumuskan pengikutnya ke dalam kemarahan bahkan dosa. ${ }^{32}$ Akan tetapi seorang pastor perlu mengetahui bahwa cara terbaik dalam memberikan nasihat untuk para pemimpin yaitu dengan menunjukan teladan kepemimpinannya di hadapan jemaat. ${ }^{33}$

\section{Pelayan dan Majikan}

Gregorius menekankan agar seorang pastor berperan membimbing seorang majikan untuk hidup dalam kerendahan hati yaitu menganggap dirinya setara dengan pelayannya. Seorang pastor juga perlu mengingatkan untuk tidak membanggakan kekuasaannya karena hal itu adalah karunia Tuhan. Rasul Paulus juga memperingatkan para majikan yang ada di jemaat Efesus (Efe $6: 9) .{ }^{34}$

\section{Orang Bijak dan Orang Bodoh}

Salomo menyebutkan, "Jikalau si pencemooh kaupukul, barulah orang yang tak berpengalaman menjadi bijak, jikalau orang yang berpengertian ditegur, ia menjadi insaf." (Ams 19:25). Dengan begitu, orang yang bijak perlu nasihati bahwa kebijakan yang dimiliki akan berakhir dengan sia-sia tanpa disertai takut akan Allah. Sebaliknya, terhadap orang yang bodoh akan berbagai macam pengetahuan harus mendapat dorongan berupa bujukan untuk mencari tahu apa yang tidak mereka ketahui. ${ }^{35}$ Teguran yang keras hanya akan membuatnya semakin menjauh dari pengetahuan. Mencari hikmat sejati yang berasal dari Allah adalah sumber dari segala sesuatu yang ada di dunia termasuk kebijaksanaan (Mat 6:33).

31 Ray Regnaldi, "Studi Etis Terhadap Ketidaktaatan Sipil Dari Perspektif Tema 'Ketaatan' Dalam Perjanjian Baru,' Jurnal Teologi Dan Pengembangan Pelayanan 2, no. 1 (2012): 329.

${ }^{32}$ Great, The Book of Pastoral Rule.

${ }^{33}$ Great.

${ }^{34}$ Great.

${ }^{35}$ Great. 


\section{Orang yang Tidak Tahu Malu dan Orang yang Pemalu}

Salomo berkata, "Suatu hardikan lebih masuk pada orang berpengertian dari pada seratus pukulan pada orang bebal." (Ams 17:10). Dengan demikian Gregorius menyarankan agar seorang pastor memberikan teguran keras yang menyentuh hati dan kesalahannnya secara langsung. Sebaliknya orang pemalu tidak memiliki kemampuan mengutarakan pendapatnya di hadapan umum dengan alasan ketidakpercayaan pada diri sendiri. Oleh sebab itu, seorang pastor perlu memberikan pujian dan penghargaan dengan menyisipkan kata-kata penegasan akan segala hal yang baik yang telah dilakukan untuk sesama bahkan kepada Allah. Salah satu contoh mengenai hal ini yaitu pujian Paulus terhadap jemaat di Filipi (Fil 4:10). ${ }^{36}$

\section{Orang yang Optimis dan Pesimis}

Metode terbaik yang perlu dilakukan seorang pastor adalah memberikan keraguan bagi orang optimis atas apa yang selama ini dianggap benar. Artinya mendorongnya untuk memertimbangkan kembali apakah kebenaran yang dipegang selama ini bersifat valid atau tidak. Jika itu bukan kebenaran yang valid maka perlu mengoreksi diri dan bertobat. ${ }^{37}$ Belajar menyangsikan dan menimbang kembali apa yang sudah dianggap benar guna memeroleh kebenaran yang lebih baik dari sebelumnya. ${ }^{38}$ Calvin Sholla Rupa menambahkan bahwa pengabdian yang tulus untuk melayani penting untuk dipertahankankan dalam hal ini. ${ }^{39}$ Belajar memberikan penguatan atas apa yang sudah diyakini dari perenungan dan pertimbangan yang matang agar tidak tumbuh menjadi pribadi yang pesimistik.

\section{Orang yang Tidak Sabar dan Orang yang Sabar}

Gregorius menyebutkan kesabaran adalah kebijaksanaan. Kesabaran juga dapat menolong seseorang memiliki kehidupan yang tenang karena mampu bertahan. Orang yang tidak sabar akan melakukan segala sesuatu secara tergesagesa hingga pada akhirnya melakukan banyak kesalahan. Oleh sebab itu,

\footnotetext{
${ }^{36}$ Great.
}

${ }^{37}$ Great.

${ }^{38}$ Haryadi Baskoro and Hendro H. Siburian, "Keseimbangan Antara Spiritualitas Dan Intelektualitas Dalam Pelayanan Pastoral-Karismatik," FIDEI: Jurnal Teologi Sistematika Dan Praktika 2, no. 1 (2019): 140-42, https://doi.org/10.34081/fidei.v2i1.37.

${ }^{39}$ Calvin Sholla Rupa', "Ciri Khas Seorang Gembala Berdasarkan Perspektif 1 Petrus 5:1-4,” Jurnal Jaffray 14, no. 2 (2016): 178, https://doi.org/10.25278/jj71.v14i2.198. 
seorang pastor perlu memberikan peringatan untuk belajar memertimbangkan segala sesuatu terlebih dahulu sebelum berkata dan bertindak.

\section{Orang yang Baik Hati dan Orang yang Iri Hati}

Menurut Salomo, Iri hati menimbulkan penderitaan pada tubuh, "Hati yang tenang menyegarkan tubuh, tetapi iri hati membusukkan tulang" (Ams 14:30). Gregorius menyebutkan mereka sebagai orang yang buta. Nasihat seorang pastor seharusnya menjadi cahaya yang menyadarkan orang yang iri hati bahwa belajar mensyukuri apa yang dimiliki, ketimbang iri hati atas apa yang ada pada orang lain. Akan tetapi, terkadang kebaikan hati yang berlebihan akan membuat seseorang menjadi pasif terhadap dirinya. Oleh sebab itu, pastor berperan mendorong mereka terlibat aktif dalam mengerjakan hal-hal baik yang diperjuangkan dalam kehidupan orang lain. ${ }^{40}$

\section{Orang yang Tulus dan Orang yang Licik}

Orang yang tulus umumnya terbiasa untuk tidak menyimpan kebenaran dengan alasan apapun. Akan tetapi, terkadang sikap ini menjadi celah yang mendatangkan penipuan, sehingga merugikan dirinya sendiri. Oleh sebab itu, mereka perlu dinasihati agar bersikap tulus sekaligus cerdik, "Sebab itu hendaklah kamu cerdik seperti ular dan tulus seperti merpati" (Mat 10:16). Orang yang tidak tulus cenderung bersikap munafik, kemudian berusaha mencari perlindungan untuk menutupi kesalahannya. Salah satu cara yang dilakukan yaitu dengan membentengi diri dengan kebohongan. Hal ini menimbulkan perasaan gelisah dan takut jika orang lain mengetahui kesalahannya. Oleh sebab itu, seorang pastor harus menasihati mereka untuk berlindung pada kebenaran sebagai pertahanan hidup yang sejati. ${ }^{41}$

\section{Orang yang Sehat dan Orang yang Sakit}

Kesehatan adalah hadiah dari Allah kepada semua umat manusia. Sebab itu, seorang pastor harus mengingatkan orang yang sehat agar menghargai hadiah tersebut dengan cara mempergunakan tubuhnya yang sehat untuk melakukan kebenaran. Orang yang menggunakan tubuhnya untuk melakukan kejahatan telah menyalahgunakan bahkan menyia-nyiakannya hadiah dari Tuhan. Bagi orang yang sakit atau terjerat dalam penyakit jasmani akibat

\footnotetext{
${ }^{40}$ Great, The Book of Pastoral Rule.

${ }^{41}$ Great.
} 
keberdosaannya perlu dinasihati agar menyukuri penderitaan yang dialami sebagai teguran dari Tuhan. Rasul Paulus juga menekankan hal tersebut (Ibr $12: 5-6){ }^{42}$

\section{Orang yang Takut Hukuman dan Tidak Takut pada Hukuman}

Orang yang takut pada hukuman harus dinasihati bahwa jika mereka ingin benar-benar bebas dari kejahatan, mereka harus takut akan hukuman kekal. Namun bukan berarti mereka harus hidup dalam ketakutan tetapi tumbuh dengan merawat cinta kasih. Karena ada tertulis, kasih yang sempurna menghilangkan ketakutan (1 Yoh. 4:18). Orang-orang yang bahkan sama sekali tidak takut akan hukuman dari kedurhakaannya harus dipukuli dengan teguran yang lebih tajam secara proporsional. Karena mereka telah tumbuh keras. ${ }^{43}$

\section{Orang yang Diam dan Orang yang Banyak Bicara}

Menurut Gregorius, orang yang diam akan menderita lebih banyak kepedihan hati. Sebagian besar kesalahan akan meluap lebih luas dalam hati karena mereka menganggap diri mereka lebih aman dan tidak terlihat oleh pencari kesalahan. Kesalahan tersebut kemudian akan meluap ke pikiran sehingga menimbulkan kesombongan tersembunyi. Seorang pastor perlu mendorong mereka untuk mengevaluasi motivasi yang terkandung dalam hatinya dan berhati-hati dengan apa yang dipikirkannya. ${ }^{44}$ Ia perlu mengingatkan orang yang banyak bicara agar menjaga lidahnya agar iblis tidak mengambil kesempatan untuk menjatuhkannya (Ams 25:28) sebab orang bijak pasti akan menahan lidahnya sampai tiba saatnya ia berbicara (Pkh. 20:7). Yakobus juga mengingatkan, "Setiap orang hendaklah cepat untuk mendengar, tetapi lambat untuk berkata-kata, dan juga lambat untuk marah” (Yak. 1:19).

\section{Orang yang Malas dan Orang yang Rajin}

Bagi si pemalas, harus diingatkan bahwa seringkali mereka tidak melakukan suatu kebaikan pada waktu yang tepat akibatnya timbul penyesalan ketika mereka ingin melakukannya, namun sudah terlambat. Salomo mengibaratkan orang malas seperti seorang yang tertidur lelap dalam kelaparan (Ams 19:15). Orang yang rajin biasanya akan berusaha melakukan segala sesuatu dengan cepat untuk mencapai tujuan. Hal ini terkadang membuatnya

\footnotetext{
42 Great.

${ }^{43}$ Great.

${ }^{44}$ Great.
} 
rentan terjatuh dalam dosa. Tentang hal ini Gregorius menjelaskan, "For he who neglects to look forward by consideration to what he is about to do advances his steps with his eyes closed". ${ }^{45}$

\section{Orang yang Lemah Lembut dan Orang yang Bersemangat}

Kelemahlembutan secara berlebihan akan berubah menjadi kelambanan dan kemudian disamaartikan dengan kemalasan. Oleh sebab itu, seorang pastor perlu menasihati agar supaya mereka belajar menambahkan ketegasan dalam kelembutan. Terhadap orang yang bersemangat seorang pastor perlu memberikan teguran untuk melengkapi semangatnya dengan roh kelemahlembutan. Sebab semangat yang disertai dengan gairah yang berlebihan akan menimbulkan amarah yang merusak. Amarah Nabal yang mengantarnya pada kematian setelah mendengar perkataan istrinya (1 Sam 25:37). ${ }^{46}$

\section{Orang yang Rendah Hati dan Orang yang Angkuh}

Biarlah orang yang rendah hati mendengar dari suara kebenaran bahwa setiap orang yang merendahkan dirinya akan ditinggikan (Luk 18:14). Biarlah orang yang rendah hati mendengar, Allah menghormati hal-hal yang dilakukan dengan kerendahan hati. Hal tersebut juga mencerminkan karakter Yesus sebagai Allah yang merendahkan diri-Nya (Mat 20:28), bahkan mengorbankan diri-Nya untuk melayani orang berdosa (Fil 2:8). Sedangkan orang yang angkuh memiliki level kesombongan yang setara dengan iblis. Sebaliknya, terhadap orang yang angkuh, seorang pastor seharusnya memberikan teguran secara perlahan namun mendalam. Nasihat yang terbaik bagi orang yang angkuh dapat digambarkan seperti mengelus seekor kuda yang terlepas dengan memberikan elusan lembut, namun memberikan cambukan setelah berhasil didekati. ${ }^{47}$

\section{Orang yang Keras Kepala dan Bimbang}

Orang yang keras kepala harus dinasihati untuk mengakui keangkuhan pikiran mereka dan belajar untuk mengalahkan diri mereka sendiri. Di samping itu, Gregorius menyebut orang bimbang adalah orang bertindak sembrono dalam menjalani kehidupan. ${ }^{48}$ Oleh sebab itu, hendaklah orang yang bimbang belajar untuk menghargai kehidupan yang telah diberikan oleh Allah. Seorang pastor

\footnotetext{
${ }^{45}$ Great.

${ }^{46}$ Great.

47 Great.

${ }^{48}$ Great.
} 
seharusnya menasihati orang yang berada dalam kebimbangan untuk berdiri teguh pada keyakinan dan iman yang dipegang. Meneladani kehidupan Kristus yang tidak pernah berubah dalam rencana-Nya untuk meyelamatkan umat-Nya.

\section{Orang yang Rakus dan Berpantang dengan Makanan}

Berbicara berlebihan, keteledoran tingkah laku dan bejat mengiringi orang yang rakus. Salah satu contohnya, orang kaya yang makan dan minum secara berlebihan kemudian menghina Lazarus (Luk 16:24). Sedangkan orang berpantang makanan akan mudah terjerat dalam ketidaksabaran. Kemudian akan berakhir pada dosa kesombongan. Sebagaimana manusia pertama jatuh dalam hal pemuasan keinginan perut (kisah Adam dan Hawa). Oleh sebab itu, seorang pastor harus memperingatkan orang rakus agar belajar mendisiplinkan diri demi kekudusan serta melepaskan diri dari keinginan akan dosa (Rom 6:19). Orang yang berpantang harus dinasihati bahwa mereka seharusnya menawarkan kepada Allah suatu pantangan yang menyenangkan Dia. Salah satunya yaitu dengan memberikan makanan yang dipantang kepada orang miskin. Selain itu, orang yang berpantang akan berbagai makanan lebih mudah jatuh dalam kesombongan. Pada awalnya, bertujuan untuk membuktikan kerendahan hati, namun kemudian menjadikannya sebagai alasan untuk dikasihani. Dalam catatan Lukas, orang Farisi juga melakukan hal tersebut (Luk 18:12) ${ }^{49}$

\section{Orang yang Suka Memberi dan Orang yang Suka Merebut Milik Orang Lain}

Orang yang suka memberi perlu dinasihati agar tidak merasa harus menghargai dan memuji diri atas dukungan yang telah diberikan kepada orang lain karena Firman Tuhan berkata "Jangan biarkan tangan kirimu tahu kebaikan apa yang dilakukan oleh tangan kananmu (Mat 6:3). Prinsip hidup memberi, merupakan kewajiban bagi orang percaya (Luk 17:10). Sedangkan mereka yang tergesa-gesa mengambil pusaka sejak masih di dunia dengan cara merebut milik orang lain dengan ketamakan tanpa sadar akan kehilangan harta warisan atau berkat yang akan diterima di Surga (kekekalan). Menjaga harta orang lain sama halnya menjaga pusaka kita di surga. Lebih baik banyak memberi untuk memerbanyak harta di Surga sedangkan lebih banyak merebut justru akan menguranginya. ${ }^{50}$

\footnotetext{
${ }^{49}$ Great.

${ }^{50}$ Great.
} 
Orang yang Menyimpan Harta bagi Diri Sendiri dan Orang yang Memberi Namun Sambil Merebut Milik Orang Lain

Bagi orang yang menyimpan harta bagi diri sendiri harus diberikan pemahaman bahwa bumi dianugerahkan kepada semua manusia sehingga hasilnya harus dinikmati bersama. ${ }^{51} \mathrm{Hal}$ tersebut dapat dibuktikan melalui kerelaan hati untuk berbagi makanan dengan fakir miskin. Hal ini membuktikan hilangnya kasih akan Allah sebab kepedulian terhadap sesama adalah simbol kepedulian kepada Tuhan. Orang yang memberi, namun sambil merebut milik orang lain harus dinasihati untuk belajar bagaimana menjaga apa yang menjadi milik mereka secara wajar sehingga tidak berjuang mendapatkan apa yang menjadi milik orang lain. Dengan begitu, ia tidak disamakan dengan orang yang hanya berhasil menghitung pemberiannya, namun gagal menghitung kebaikan yang telah ia terima. ${ }^{52}$ Stephen Tong menyebut mereka sebagai pencuri karena menghilangkan hak kepemilikan orang lain. ${ }^{53}$

\section{Orang yang Tidak Suka Berdamai dan Orang yang Suka Berdamai}

Orang yang tidak suka berdamai harus diperingati bahwa tanpa persatuan dengan sesama maka sia-sialah kebijaksanaan atau kemampuan yang mereka miliki. Perselisihan adalah tanda ketiadaan kedamaian dan kasih. Hidup tanpa kasih mendatangkan perpecahan dan hukuman kekal sebaliknya bagi orang yang telah ada dalam perdamaian perlu keberanian untuk saling menegur kesalahan sesamanya. Jangan merasa takut jika nantinya dijauhi dan ditolak, bila hal itu terjadi hendaklah tidak memengaruhi kedamaian yang ada dalam hatimu. ${ }^{54}$

\section{Orang yang Menabur Perselisihan dan Kedamaian}

Orang yang menabur perselisihan disamakan dengan orang yang menaburkan benih lalang di antara gandum sehingga akan berakhir dalam kebinasaan. Mereka perlu mendengarkan bahwa satu kesalahan kecil yang telah diperbuat akan menghapus semua kebaikan di hati semua orang yang melihatnya. Sedangkan di sisi lain, orang yang menabur kedamaian perlu waspada dengan siapa ia membagikan kedamaian tersebut. Jika nantinya yang dihadapi adalah orang yang giat menabur kejahatan, maka ia harus

${ }^{51}$ Firman Panjaitan and Hendro Hariyanto Siburian, "Misi Kristologi Dalam Konteks Kebudayaan," LOGIA: Jurnal Teologi Pentakosta 1, no. 1 (2019): 54-57, https://doi.org/10.37731/log.v1i1.19.

${ }^{52}$ Great, The Book of Pastoral Rule.

${ }^{53}$ Stephen Tong, Kristen Sejati, vol. 4 (Surabaya: Momentum, 2011), 53.

${ }^{54}$ Great, The Book of Pastoral Rule. 
memberanikan diri untuk menolak untuk menabur benih itu sekalipun dengan alasan menjaga kedamaian. ${ }^{55}$

Orang yang Salah Mengerti Kebenaran Alkitab dan Orang yang Mengerti tetapi Tidak Memiliki Kerendahan Hati

Orang yang salah mengerti kebenaran Alkitab harus dinasihati bahwa kebenaran dalam Alkitab justru adalah lentera yang menerangi jalan kehidupan sehingga secara tidak langsung hal itu tidak hanya menjadi pengetahuan secara kognitif melainkan perlu dilakukan. Tidak hanya pintar membimbing orang lain dalam kemuliaan namun menolak kebenaran untuk diri sendiri. Orang yang pintar dalam memerkatakan kebenaran Alkitab namun tidak melakukannya dengan kerendahan hati melainkan dengan kesombongan akan menerima hukuman. Orang seperti ini sama seperti seorang dokter yang terampil mengobati orang lain namun tanpa sadar mencelakakan dirinya dengan racun. ${ }^{56}$

Orang yang Menolak Pelayanan Khotbah karena Merasa Ketidaklayakan yang Berlebihan dan Orang yang Menerimanya dengan Terpaksa

Orang yang menolak pelayanan khotbah karena merasa ketidaklayakan yang berlebihan harus dinasihati agar tidak selalu menjadikan hal-hal kecil sebagai alasan untuk membatalkan hal-hal yang besar seperti pelayanan. Karena dengan begitu ia disamakan seperti seorang dokter yang hanya menyimpan obat berharga untuk dirinya sendiri, sehingga mengabaikan keselamatan jiwa-jiwa yang sedang sekarat karena dosa. Hal ini menunjukan bahwa betapa pentingnya mempersiapkan diri dalam kuasa Allah terlebih dahulu sebelum melayani. ${ }^{57}$

\section{Orang yang Berhasil dan Orang yang Tidak Ingin Melakukan Apa-apa}

Orang yang berhasil mendapatkan semua keinginannya di dunia harus diperingatkan untuk menjaga diri dari hukuman yang nantinya akan datang dalam kekekalan. Mereka harus senantiasa memperhatikan harta surgawi di samping kesenangan yang telah diperoleh dari dunia. Karena dunia hanya memberikan harta dan kesenangan yang sementara. Bagi orang yang menginginkan hal-hal duniawi namun tidak pernah berhasil mendapatkannya diberikan pengharapan akan harta mulia yang sedang menantinya di Surga. ${ }^{58}$

\footnotetext{
55 Great.

${ }^{56}$ Great.

57 Great.

${ }^{58}$ Great.
} 


\section{Orang yang Menikah dan Orang yang Tidak Menikah atau Lajang}

Orang yang menikah perlu mengetahui bahwa mereka perlu menjalin kebaikan bersama pasangan di dunia dengan rasa tanggung jawab yang besar pada Allah. Tetapi jika ia memiliki hal-hal yang ada di dunia untuk melayani perjalanannya biarkan ia berharap untuk hal-hal yang dari Allah sebagai buah dari akhir perjalanannya. Pastor perlu menasihati agar orang yang melajang yang tidak mampu menahan keinginannya untuk mengikat diri dalam pernikahan. Dengan demikian, seseorang tidak akan terjerumus ke dalam dosa percabulan yang mendatangkan hukuman dari Tuhan (1 Kor 7:1-2). ${ }^{59}$

Orang yang Berdosa karena Nafsu Daging dan Orang yang Mampu Mengendalikannya

Dalam Galatia 1:4 Rasul Paulus menggambarkan kebaradaan dunia yang begitu jahat dan selalu berusaha memisahkan orang percaya dari Allah. Ayat ini juga menjelaskan tentang pengorbanan Kristus yang sanggup melepaskan manusia dari dosa. Dengan alasan ini setiap orang yang telah menerima karunia dan pengampunan dosa seharusnya tidak lagi melakukan dosa yang sama. Ini merupakan suatu perintah ilahi yang menjadi sebuah anugerah dari Allah. Orang yang mampu mengendalikan hawa nafsu harus menahan diri dalam kerendahan hati dan tidak menyombongkan diri. Karena terkadang orang yang mungkin dianggap hina justru dianggap benar dihadapan Allah. Seperti halnya doa pemungut cukai yang didengarkan oleh Allah. Dengan demikian, mereka yang tidak melakukan kesalahan perlu dinasihati untuk menjalani kehidupan dengan mengasihi Tuhan dan sesama dengan kerendahan hati. ${ }^{60}$

Orang yang Menyesali Dosa Perbuatan dan Orang yang Menyesali Dosa Pemikiran

Seorang pastor perlu menasihati bahwa terkadang penyesalan yang berlebihan dapat menjadi alat iblis untuk membinasakan mereka seperti halnya Dina (Kej 34:3). Oleh sebab itu, mereka harus dinasihati agar percaya diri oleh pengharapan agar tidak tumbuh lamban dalam penyesalan yang menyesatkan. Seberapa besar dosa baik yang tersimpan dalam pikiran atau yang terbukti dalam perbuatan perlu mendapat pengampunan dari Tuhan. Orang yang

${ }^{59}$ Great.

${ }^{60}$ Great. 
melakukan dosa dalam pikirannya perlu diingatkan akan adanya penghakiman yang akan datang dari Tuhan (1 Sam 16:7). ${ }^{61}$

Orang yang Menyesali Dosanya tetapi Tidak Ingin Melepaskannya dan Orang yang Meninggalkan Dosanya tetapi Tidak Menyesalinya

Bagi mereka seorang pastor perlu memberikan nasihat Rasul Petrus yang berkata, "Anjing kembali lagi ke muntahnya, dan babi yang mandi kembali lagi kekubangannya" (2 Pet 2:22). Artinya dosa yang membebani hidup sehingga dikeluarkan dengan penuh penyesalan, sudah selayaknya untuk tidak dilakukan lagi. Jika tidak disingkirkan, maka dosa itu akan terbiasa dilakukan dan menjadi sahabat karib bagi yang melakukannya. Hal ini secara otomatis telah menjadikan Allah menjadi musuh dalam hidupnya (Yak 4:4). Kasih Allah hadir untuk menyembuhkan semua luka dosa manusia. Dengan alasan inilah, orang yang kedua perlu diingatkan untuk menyukuri kasih Allah itu dengan penuh air mata. Jadi, air mata penyesalan diibaratkan sebagai proses "rasa sakit" akibat memar dari luka dosa. ${ }^{62}$

Orang yang Memuji Hal-hal Melanggar Hukum Secara Sadar dan Orang yang Menghindari Pelanggaran namun Tetap Melakukannya

Hal ini menunjukan bahwa suatu dosa yang telah dilakukan kemudian dengan berani dibicarakan di depan umum akan mengundang hal yang lebih buruk. Salah satunya, orang lain yang mendengar hal itu akan terdorong untuk berani melakukan dosa. Sebaliknya orang yang menolak dosa dengan tegas melalui ucapan mereka namun tetap melakukannya adalah orang yang tidak bertanggung jawab. Ini merupakan suatu kesalahan yang besar karena telah menyia-nyiakan pengetahuan yang diberikan Tuhan. ${ }^{63}$

\section{Orang yang Berdosa karena Tidak Disengaja dan Disengaja}

Salomo menyebutkan, orang yang melakukan dosa dengan tidak sengaja tanpa sadar telah membiarkan dirinya terbuai pada kesenangan dunia yang menuju kebinasaan. Demikian tulisnya, "Engkau akan berkata, "Orang memukul aku, tetapi aku tidak merasa sakit. Orang memalu aku, tetapi tidak kurasa. Bilakah aku siuman? Aku akan mencari anggur lagi." (Ams 23:35). Orang seperti ini, tanpa sadar telah melepaskan kemudinya di tengah gelombang

${ }^{61}$ Great.

${ }^{62}$ Great.

${ }^{63}$ Great. 
duniawi yang siap menerkanmnya. Dan iblis akan mengambil kesempatan ini untuk menjadikan mereka sebagai alat untuk mencapai tujuannya. Oleh sebab itu, seorang pastor perlu mengingatkan mereka yang seringkali melakukan dosa tanpa sengaja untuk selalu mempersiapkan diri dengan baik sebelum musuh itu datang menyerang. Bagi mereka yang dengan sengaja melakukan dosa sekalipun tahu akibat yang akan terjadi ibarat orang yang menghunus pedang pada tubuhnya sendiri. ${ }^{64}$

Orang yang Sering Jatuh dalam Kesalahan Kecil tetapi Terhindar dari Kesalahan Besar dan Sebaliknya yang Tidak Pernah Jatuh pada Kesalahan Kecil namun Terjerumus Dalam Penderitaan yang Besar

Bagi yang sering jatuh dalam kesalahan kecil tetapi terhindar dari kesalahan besar, perlu diingatkan agar konsisten dalam menjaga kebenaran Allah dalam dirinya. Bagi orang yang tidak pernah jatuh pada kesalahan kecil namun terjerumus dalam penderitaan yang besar, Gregorius menuliskan bahwa orang-orang seperti ini adalah orang yang berpura-pura hidup dalam kesucian. Sehingga ia dengan sengaja membiarkan dirinya jatuh dalam kesalahan yang lebih besar. Kemudian menerima penderitaan yang lebih berat dibandingkan akibat dari kesalahan kecil yang selalu ditolak. ${ }^{65}$

Orang yang Tidak Memulai Apapun dan Orang yang Memulai namun Tidak Menyelesaikannya

Bagi orang yang tidak memulai apapun, seorang pastor perlu menunjukkan bahwa betapa sia-sianya berpegang dan tinggal pada posisi yang selama ini dianggap nyaman namun tanpa tujuan. Sehingga perlu bergerak dan mengerjakan hal yang benar bagi Allah. Sebab Allah tidak menjadikan manusia tanpa tujuan (Yer 1:10). Sebaliknya bagi orang yang tidak menyelesaikan apa yang telah dimulai, Gregorius menyatakan bahwa ia telah meruntuhkan suatu bangunan kebenaran yang telah dibangun dengan tangannya sendiri. Oleh sebab itu, mereka perlu menjaga semangatnya yang semula. ${ }^{66}$

Orang yang Terlihat Baik namun Menyembunyikan Banyak Kejahatan dan Orang yang Terlihat Buruk namun Sebenarnya Melakukan Kebaikan Secara Diam-diam

\footnotetext{
${ }^{64}$ Great.

${ }^{65}$ Great.

${ }^{66}$ Great.
} 
Orang yang terlihat baik namun menyembunyikan banyak kejahatan disamakan dengan orang yang munafik (ahli Taurat) karena mereka selalu memperhatikan pujian manusia, tetapi tidak memerhatikan akibat yang nanti akan dituntut dalam kekekalan. Karena seberapa dalam seseorang menyembunyikan kebusukannya tetap akan terlihat dihadapan Allah. Karena Allah mengenal hati manusia. Sedangkan bagi mereka yang senang menunjukkan keburukan di hadapan manusia, namun sebenarnya melakukan kebaikan dalam hati adalah orang yang patut diberi pujian. Namun, mereka perlu diingatkan juga bahwa terkadang kebaikan yang nyata akan memberikan pengaruh yang lebih besar bagi kehidupan orang lain dibandingkan kebaikan yang tersembunyi. ${ }^{67}$

Mengenai Pemberian Nasihat di Kalangan Umum yang Menghasilkan Solusi bagi Permasalahan Antar Pribadi

Kebenaran firman Tuhan, baik yang disampaikan di hadapan umum maupun secara pribadi, bertujuan untuk menyembuhkan luka keberdoasaan seseorang; bukan sebaliknya membuat seseorang semakin menjauh dari Allah. Hanya kekuatan Allah yang dapat membawa kebenaran Firman-Nya kepada setiap hati manusia. Sedangkan pastor menjadi alat dan sarana ditangan Allah untuk melakukan hal tersebut. Oleh sebab itu, seorang pastor perlu selalu bersandar pada Allah. Dengan cara merendahkan diri dan memohon hikmat dari Allah sebelum menyampaikan khotbah di hadapan umum (1 Tes. 1:5). ${ }^{68}$

\section{Nasihat kepada Orang yang Menyembunyikan Motif Kejahatan}

Begitu mudah menghadapi roh perlawanan yang tersimpan dalam hati dan belum tumbuh keluar karena jika perlawanan itu tumbuh keluar maka dosa akan semakin kuat dalam diri orang tersebut. Seorang pastor perlu memberikan perasaan takut tentang akibat dari dosa yang disimpan terlalu lama terhadap orang yang menyembunyikan dosanya, yaitu hukuman kekal yang siap menantinya diakhir perjalanan hidup. ${ }^{69}$

Cara Menasihati dengan Membiarkan Sifat-sifat yang Ringan guna Menghilangkan Sifat yang Lebih Berat dan Jahat

\footnotetext{
${ }^{67}$ Great.

${ }^{68}$ Great.

${ }^{69}$ Great.
} 
Terkadang sifat-sifat buruk yang sepele harus dibiarkan demi mencegah dosa yang lebih berat terjadi. Gregorius menyimpulkan bahwa seorang pastor perlu memiliki strategi yang baik sehingga ketika menyembuhkan satu dosa tidak menumbuhkan penderitaan yang lainnya. ${ }^{70}$

\section{Nasihat yang Dalam Tidak Seharusnya Diberikan Bagi Jiwa yang Lemah}

Kebenaran yang disampaikan dengan terlalu dalam kepada orang yang tidak mampu mencernanya akan berakhir dengan sia-sia. Sebaliknya, memberikan nasihat yang ringan kepada orang yang mampu menerima hal yang dalam pun akan berakhir dengan sia-sia. Paulus dalam pelayananya, mengungkapkan bahwa terkadang ia harus berbicara kepada setiap orang dengan cara yang berbeda. Diantaranya berbicara tentang hal-hal rohani bagi yang mampu menerimanya. ${ }^{71}$

\section{Berkhotbah dengan Kata-kata dan Perbuatan}

Gregorius menyebutkan pada kenyataannya perbuatan lebih berbicara keras daripada perkataan. Bahkan Kristus pun meninggalkan jejak penderitaanNya agar diikuti semua orang yang percaya (1 Pet 2:21). Oleh sebab itu, seorang pastor harus terlebih dahulu mengoreksi dirinya sendiri sebelum melayani jemaat Tuhan. ${ }^{72}$

\section{Memiliki Kerendahan Hati}

Kerendahan hati yang dilakukan seorang pastor selain dihadapan Tuhan, hal ini juga dapat terlihat dalam kehidupannya bersama dengan jemaat yang dipimpin. Secara umum kerendahan hati tercermin dari karakter yang nyata. Yen Edwin menyebutkan karakter seorang hamba Tuhan yang rendah hati akan selalu menujukan sifat kehambaan seperti yang Yesus lakukan yaitu tercermin dari kata-kata yang keluar dari mulut, terungkap dari sikap kepada bawahan, dan keputusan yang diambil berhubungan antara pemimpin dengan bawahan. Pemimpin bukan untuk dilayani tapi untuk melayani bawahan, memberi dorongan untuk maju, memberi kesempatan untuk maju, sehingga bawahan atau pengikut (jemaat) memiliki kemampuan terus berkembang. ${ }^{73}$

${ }^{70}$ Great.

${ }^{71}$ Great.

${ }^{72}$ Great.

${ }^{73}$ Edwin Gandaputra Yen, "Yesus Kristus Sang Hamba Tuhan: Kriteria Dan Refleksi Seorang Hamba Tuhan," Jurnal Teologi Dan Pengembangan Pelayanan 2, no. 1 (2012): 241. 
Kerendahan hati adalah sikap hati maupun karakter yang menghamba dan melayani dihadapan Tuhan maupun manusia. Dengan menjaga hati agar tidak memuji kemampuan diri sendiri dan siap sedia untuk melayani sesama terlebih khusus jemaat yang dipimpin. ${ }^{74}$

\section{Simpulan}

Pelayanan pastoral merupakan suatu kehidupan yang membutuhkan berbagai keterampilan dan empati yang melibatkan pikiran, hati, dan perbuatan yang penuh totalitas. Karena segala hal yang dilakukan seorang pastor tidak terlepas dari pimpinan Roh Kudus. Allah adalah pemilik otoritas tertinggi yang harus dilayani bukan kepentingan diri sendiri. Oleh sebab itu, seorang pastor perlu melatih dirinya dalam berbagai aspek seperti emosi, pengetahuan, dan sosial serta tentunya spiritual yang tertanam kuat di dalam Allah. Sebab melayani domba-domba Allah perlu ketekunan, kesabaran, dan kerendahan hati yang tinggi dari seorang pastor. Pelayanan adalah sebuah kepercayaan dan anugerah dari Allah. Oleh sebab itu, kepercayaan tersebut harus dijaga dengan baik oleh seorang pastor dengan cara menjalankan pelayanan dengan benar yang bertujuan menuntun setiap jiwa yang haus menuju air kehidupan yaitu Kristus dan menyatakan bahwa segala perbuatan dosa bertentangan dengan kehendak Allah. Dalam melakukannya pasti ada risiko yang selalu menanti dari setiap perbuatan yang dilakukan manusia. Memberikan nasihat yang bermanfaat untuk mengobati luka dosa setiap umat melalui pemberian nasihat yang tepat dan benar. Pada akhirnya, kerendahan hati menjadi kunci yang menjadi pengikat segalanya dalam kehidupan pelayanan pastoral di gereja. Oleh sebab itu, gereja perlu mengadakan pelatihan kecakapan bagi para rekan-rekan sepelayan secara berkala. Agar pengajaran Firman Allah yang disampaikan dapat tersampaikan dengan baik. Selain itu, menyediakan wadah khusus bagi para pengajar gereja untuk mempelajari nasihat-nasihat mana yang benar dan tepat yang dibutuhkan setiap orang sesuai dengan kriteria posisi atau karakter yang dimiliki. Baik dalam pelayanan terhadap orang dewasa, pemuda-remaja, maupun anak-anak. Dengan begitu, gereja menjalankan fungsinya sebagai terang melalui usaha penyusunan strategi yang tepat untuk mendukung pemberitaan kebenaran Allah. Melalui hal ini juga gereja dapat memperbaharui sistem gereja menjadi lebih baik.

${ }^{74}$ Great, The Book of Pastoral Rule. 


\section{Daftar Pustaka}

Associated Press. "Pemecatan 400 Pendeta Oleh Vatikan.” Jawaban.com, 2012.

Bangun, Yosafat. Integritas Pemimpin Pastoral. Yogyakarta: Andi, 2014.

Baskoro, Haryadi, and Hendro H. Siburian. "Keseimbangan Antara Spiritualitas Dan Intelektualitas Dalam Pelayanan Pastoral-Karismatik." FIDEI: Jurnal Teologi Sistematika Dan Praktika 2, no. 1 (2019): 123-44. https://doi.org/10.34081/fidei.v2i1.37.

Carothers, Marlin. Jatuhnya Seorang Hamba Tuhan. Malang: Gandum Mas, 1990.

Coniaris, Anthony M. Philokalia: The Bible of Orthodox Spirituality. Minneapolis: Library of Congress, 1998.

Great, Gregorius The. The Book of Pastoral Rule. New York: St. Vladimir's Seminary Press, 2007.

Hommes, Anne. Perubahan Peran Pria Dan Wanita Dalam Gereja Dan Masyarakat. Jakarta: BPK Gunung Mulia, 1992.

Jefferson, Charles. The Minister as Shepherd. Hongkong: Mimery Press, 1997.

Panjaitan, Firman, and Hendro Hariyanto Siburian. "Misi Kristologi Dalam Konteks Kebudayaan." LOGIA: Jurnal Teologi Pentakosta 1, no. 1 (2019): 42-59. https://doi.org/10.37731/log.v1i1.19.

Regnaldi, Ray. "Studi Etis Terhadap Ketidaktaatan Sipil Dari Perspektif Tema 'Ketaatan' Dalam Perjanjian Baru." Jurnal Teologi Dan Pengembangan Pelayanan 2, no. 1 (2012): 329.

Rupa', Calvin Sholla. "Ciri Khas Seorang Gembala Berdasarkan Perspektif 1 Petrus 5:1-4." Jurnal Jaffray 14, no. 2 (2016): 165. https://doi.org/10.25278/jj71.v14i2.198.

Sanders, J.Oswald. Kepemimpinan Rohani. Bandung: Kalam Hidup, 2017.

Tidball, Derek J. Teologi Pengembalaan. Malang: Gandum Mas, 1995.

Tong, Stephen. Kristen Sejati. Vol. 4. Surabaya: Momentum, 2011.

Yen, Edwin Gandaputra. "Yesus Kristus Sang Hamba Tuhan: Kriteria Dan Refleksi Seorang Hamba Tuhan." Jurnal Teologi Dan Pengembangan Pelayanan 2, no. 1 (2012): 241. 